\title{
PEMAKNAAN JEMAAH TENTANG KHOTBAH JUMAT BERBAHASA ARAB DI MASJID AL-HIDAYAH DESA PUPUT KECAMATAN SIMPANG KATIS BANGKA TENGAH
}

\author{
Ruzaipah \\ Universitas Islam Negeri Sunan Kalijaga Yogyakarta \\ muhammadruzaipah15@gmail.com
}

Received: 05/08/2020, Accepted: 07/08/2020, DOI: 10.32923/sci.v5i1.1343

\begin{abstract}
ABSTRAK
Penelitian ini mengkajibagaimana persepsi masyarakat sebagai jamaah terhadap khotbah Jumat berbahasa Arab di Desa Puput Kecamatan Simpang Katis Kabupaten Bangka Tengah. Penelitian ini adalah penelitian kualitatif deskriptif. Data diperoleh dari hasil pengamatan secara langsung pelaksanaan khotbah Jumat di Desa Puput. Penelitian ini menggunakan metode wawancara mendalam, observasi, serta dokumentasi. Setelah data terkumpul penulis melakukan analisis data, sehingga penulis menemukan kesimpulan yang merupakan jawaban dari rumusan masalah. Hasil penelitan ini menunjukkan bahwa pelaksanaan khotbah Jumat di Desa Puput sesuai dengan syarat dan rukun khotbah, kemudian masyarakat Desa Puput mempunyai persepsi yang berbeda mengenai khotbah Jumat berbahasa Arab, yaitu secara mayoritas masyarakat setuju, dan sebagian kecil kurang setuju dengan khotbah Jumat berbahasa Arab dengan alasan yang berbeda pula. Persepsi masyarkat Desa Puput terhadap khotbah Jumat berbahasa Arab karena alasan pendidikan masyarakat Desa Puput, yaitu menyadarkan masyarakat untuk patuh kepada tokoh agama, menjaga warisan budaya yaitu melestarikan bahasa Arab dalam ritual ibadah, mendorong masyarakat untuk mempelajari bahasa Arab dan membentuk sikap toleransi.
\end{abstract}

\section{Kata Kunci: Khotbah Jumat, bahasa Arab, Persepsi masyarakat.}

\section{Pendahuluan}

Tulisan ini berangkat dari fenomena ritual keagamaan yaitu Khotbah Jumat bebahasa Arab yang berlangsung di Masjid Al-Hidayah Desa Puput. Khotbah yang seharusnya disampaikan dengan bahasa yang jelas dan dimengerti oleh para jemaah, di mana khotbah memiliki kedudukan penting dalam Islam, yaitu sebagai penopang utama dalam pendidikan Islam di seluruh dunia. Khotbah Jumat juga merupakan salah satu sarana penting guna menyampaikan pesan, nasehat, peringatan,dan pengajaran kepada orang lain atau suatu kaum.

Dalam pelaksanaannya khotbah Jumat memang tidak terlepas dari bahasa Arab. Jumhur ulama berpendapat bahwa khotbah Jumat harus disampaikan dengan bahasa Arab. khotbah Jumat sebaiknya menggunakan bahasa Arab. Alasannya, karena Rasulullah Saw, dan para sahabat senantiasa melaksanakan khotbah Jumat itu dengan bahasa Arab, tidak pernah bahasa selain Arab. Mazhab maliki berpendapat bahwa khotbah disyaratkan agar menggunakan bahasa Arab sekalipun jemaahnya bukan orang Arab dan tidak mengerti bahasa Arab.

Mazhab Syafi'i berpendapat bahwa disyaratkan menyampaikan rukun khotbah dengan bahasa Arab jika ada yang bisa berbahasa Arab, namun jika tidak memungkinkan, maka boleh berkhotbah dengan bahasa selain Arab. Sebagian pendapat mengatakan bahwa khotbah harus disampaikan dengan bahasa yang dipahami oleh para jemaah, agar para jemaah dapat mengerti dan memahami isi dari khotbah yang disampaikan. Khotbah dilaksanakan menggunakan bahasa Arab pada setiap rukun-rukunnya, namun nasihat dan ajaran-ajaran Islam yang ingin disampaikan harus menggunakan bahasa yang dipahami oleh jemaah. Artinya, jika khotbah Jumat itu menggunakan bahasa Arab secara keseluruhan maka tujuan khotbah untuk menyampaikan ajaran dan nasehat kepada jemaah bisa dikatakan belum tersampaikan kepada para jemaah.

Berangkat dari penjelasan di atas dapat dipahami bahwa khotbah Jumat sebaiknya disampaikan dengan bahasa yang dimengerti oleh para jemaah selaku pendengar khotbah agar tujuan khotbah dapat tersampaikan. Berbeda dengan pelaksanaan khotbah Jumat di Desa Puput yang berbahasa Arab, dapat disimpulkan bahwa 
para jemaah tidak mengerti dengan khotbah yang disampaikan oleh khotib. Menariknya meskipun jemaah tidak mengerti dengan makna khotbah yang disampaikan dalam khotbah Jumat berbahasa Arab, para jemaah tetap mengikuti shalat Jumat di masjid Al-Hidayah ini, tentunya para jemaah memiliki persepsi yang beragam terkait pemahaman khotbah Jumat berbahasa Arab di Masjid al-Hidayah Desa Puput dan hal inilah yang akan penulis paparkan atau jelaskan dalam tulisan ini.

\section{Metode Penelitian}

Penelitian ini menggunakan metode penelitian kulitatif deskriptif, di mana penelitian tersebut berusaha memberikan gambaran atau uraian yang bersifat deskriptif mengenai suatu objek yang diteliti secara sistematis dan aktual mengenai fakta-fakta yang ada. Melalui penelitian deskriptif, peneliti berusaha mendeskripsikan peristiwa atau kejadian yang menjadi pusat perhatian tanpa memberikan perlakuan khusus terhadap peristiwa tersebut. ${ }^{1}$ Dalam hal ini, penulis ingin menggambarkan seluruh pelaksanaan mengenai persepsi masyarakat terhadap khotbah Jumat berbahasa Arab di Desa puput.

\section{Pembahasan}

\subsection{Pemahaman Jemaah Masjid Al-Hidayah Desa Puput Terhadap Khotbah Jumat berbahasa Arab}

\section{1) Wujud Kepatuhan dan Mengahargai Tokoh Agama}

Pelaksanaan khotbah Jumat berbahasa Arab di Masjid Al-Hidayah Desa Puput berjalan sesuai syarat dan rukun khotbah. Jemaah terlihat sangat khusyuk saat mendengarkan khotbah dan tidak ditemukan jemaah yang berbicara pada saat khotbah Jumat berlangsung, hal ini menandakan khotbah Jumat berbahasa Arab ini bisa memberikan kesadaran kepada jemaah untuk tidak berbicara pada saat khotbah berlangsung. Hal ini sejalan dengan perintah untuk diam dan mendengarkan khotbah saat khotbah berlangsung sebagaimana pandangan jumhur ulama bahwa mendengarkan khotbah itu wajib dan tidak boleh berbicara ketika khatib sedang berkhotbah. ${ }^{2}$

Terkait pernyataan di atas, dipahami bahwa khotbah Jumat berbahasa Arab di Masjid Al-Hidayah Desa Puput secara tidak langsung dapat membuat masyarakat selaku jemaah, untuk tidak berbicara atau diam dan mendengarkan selama khatib berkhotbah. Hal ini menandakan masyarakat Desa Puput memahami bahwa diperintahkan untuk mendengarkan khotbah dengan baik saat khotbah berlangsung.

Dalam pelaksaan khotbah Jumat berbahasa Arab penulis menemukan hal yang menarik yaitu yang menjadi khatib hanyalah beberapa orang, yang secara bergantian dari minggu ke minggu, tidak pernah ada orang lain yang diberikan kesempatan untuk menjadi khatib. Tentunya pengurus Masjid memiliki dasar tersendiri akan hal tersebut.

Sebagaimana yang diungkapkan oleh Hasan M. Amin selaku ketua Masjid Al-Hidayah Desa Puput menjelaskan bahwa, yang bertugas sebagai khatib adalah mereka yang memiliki garis keturunan tertentu, yakni mereka yang memiliki garis keturunan yang menunjukan bahwa ayah mereka ataupun kakek mereka pernah menjadi khatib, sehingga bukan sembarang orang yang bisa menduduki posisi khatib. Kemudian mereka yang telah dipercaya untuk menjadi khatib dan imam harus mencerminkan perilaku dan tingkah laku yang baik di manapun berada, dan harus menjadi suri teladan yang baik bagi masyarakat. Mereka yang bertugas menjadi khatib harus datang ke Masjid lebih awal pada hari Jumat agar bisa dijadikan contoh bagi masyarakat untuk bersegera menuju ke Masjid melaksanakan salat Jumat. ${ }^{3}$

Berdasarkan apa yang dijelaskan oleh ketua Masjid di atas bahwa mereka yang menjadi khatib mempunyai garis keturunan yang baik, yaitu orang tua mereka yang pernah menjadi khatib atau mereka yang aktif sebagai petugas dalam kegiatan keagamaan di Desa Puput. Mereka yang dipercaya untuk menjadi khatib harus bisa menjadi suri teladan yang baik yang bisa dijadikan contoh oleh masyarakat. Selain itu mereka harus datang lebih awal pada pelaksanan salat Jumat agar bisa menjadi perhatian bagi masyarakat untuk bersegera menuju ke Masjid.

Dari berbagai data bahwa tindakan menggunakan bahasa Arab dalam berkhotbah tidak begitu saja dilakukan di Masjid Al-Hidayah Desa Puput, namun para tokoh agama telah terlebih dahulu melalui tahapantahapan dan berbagai pemahaman mereka yang mendasari terlaksananya khotbah Jumat berbahasa Arab tersebut. Seperti data yang ditemukan di lapangan menyebutkan, khatib dan ketua Masjid terlebih dahulu mengetahui bagaimana kondisi lingkungan masyarakat di Desa Puput, dan mengetahui bahwa khotbah Jumat berbahasa Arab tersebut telah dilakukan sejak dahulu dan tidak pernah diganti.

\footnotetext{
${ }^{1}$ Juliansyah Noor, Metodologi Penelitian Skripsi, Tesis, Disertasi, dan Karya Ilmiah, (Jakarta: Kencana, 2015), hlm. 3435 .

${ }^{2}$ Ibnu Qoyyim al-Jauziyah, Fiqih Salat..., hlm.224

${ }^{3}$ H. Hasan M. Amin, ketua masjid Al-Hidayah, Wawancara, Puput 13 Juli 2018
} 
Seperti apa yang di utarakan oleh ketua Masjid, bahwa masyarakat Desa Puput masih patuh terhadap apa yang telah diwariskan sebelumnya, sehingga sangat cocoklah Masjid Al-Hidayah melaksanakan khotbah berbahasa Arab. Selain itu mereka juga mengambil keputusan tersebut tidak secara langsung begitu saja, akan tetapi melalui musyawarah dan mufakat sehingga mereka memiliki kesamaan pendapat tentang makna khotbah, yang bagi mereka khotbah merupakan rukun dari ibadah Jumat yang wajib dilaksanakan, dan mereka menilai khotbah berbahasa Arab merupakan hal yang baik karena kegiatan tersebut sesuai dengan sunnah Nabi. Meskipun ada jemaah yang tidak paham itu bukan masalah, karena mereka menganggap jemaah hanya di perintahkan duduk, diam tenang dan dengarkan. ${ }^{4}$

Penulis melihat tingkat pemahaman dan pengetahuan ilmu agama antara khatib dan ketua Masjid, mereka semua memiliki tingkat yang sama dalam pemahaman dan pengetahuan ilmu agama, sehingga hampir tidak ada perbedaan pendapat secara umum mengenai makna khotbah Jumat yakni sebagai rukun ibadah Jumat, namun setiap informan memiliki motif-motif tertentu untuk tetap mendukung pelaksanaan khotbah berbahasa Arab ini, dan tidak ada maksud dan motif yang ingin merubah atau mengganti pelaksanaan dari khotbah Jumat berbahasa Arab ini sehingga pelaksanaan khotbah berbahasa Arab ini bisa terus berlangsung.

Pada diri jemaah Jumatan yang hadir dan mengikuti ibadah salat Jumat di Masjid Al-Hidayah dan mendengarkan khotbah, tentunya mereka memiliki pemahaan ataupun persepsi yang berbeda-beda mengenai pelaksanaan khotbah Jumat berbahasa Arab. Hal tersebut dapat diihat dalam hasil wawancara yang diambil ataupun dilakukan dengan para jemaah yang menunaikan ibadah Jumat dan mendengarkan khotbah Jumat, meskipun semua informan mengaku tidak paham secara keseluruhan apa isi dari khotbah yang disampaikan oleh khatib, para jemaah tetap mengikuti ibadah Jumat di Masjid Al-Hidayah karena mereka mengikuti apa yang dilakukan para tokoh agama disana yang menunaikan ibadah Jumat di Masjid Al-Hidayah.

Adapun untuk mengetahui pemahaman ataupun persepsi jemaah Jumat penulis melakukan wawancara kepada jemaah Jumaatan di Masjid Al-Hidayah Desa Puput, dan akhirnya penulis memahami pemahaman jemaah terhadap khotbah Jumat berbahasa Arab di Masjid Al-Hidayah Desa Puput diantaranya sebagaimana yang dijelaskan oleh Suhar salah satu jemaah salat Jumat menjelaska bahwa, meskipun tidak mengerti ataupun tidak paham dengan makna khotbah Jumat berbahasa Arab, tetapi tetap mengikuti pelaksanaan salat Jumat di Masjid Al-Hidayah karena sikap patuh dan setia mengikuti setiap keputusan yang ditetapkan oleh tokoh agama, dan yakin bahwa para tokoh agama tidak mungkin memutuskan suatu hal dengan sembarangan, apalagi ini menyangkut masalah khotbah Jumat yang merupakan masalah peribadatan. ${ }^{5}$

Berdasarkan tanggapan di atas, kelangsungan khotbah Jumat berbahasa Arab di Desa Puput tidak terlepas dari pengaruh dari tokoh agama yang masih sangat dipatuhi dan dianggap memiliki karisma oleh masyarakat.

Selanjutnya Nomli selaku jemaah dan dianggap sejarawan ataupu $\mathrm{n}$ orang yang mengerti sejarah perkembangan Islam di Desa Puput menjelaskan bahwa dari dulu sampai sekarang khotbah Jumat di Desa Puput selalu menggunakan bahasa Arab dan tidak pernah diganti. Khotbah ini dibuat oleh dua tokoh agama yang dianggap masyarakat sebagai guru besar atau kiai yang bernama kiai Johar dan kiai Palimbani yang dimana mereka adalah orang menyebarkan dan mengajarkan ajaran Islam di Desa Puput, dan dianggap sebagai tokoh besar besar yang akan selalu kami ingat. Oleh karena itu masyarakat sangat patuh dan setia terhadap keputusan yang ditetapkan, sama halnya dengan keadaan masyarakat sekarang ini yang patuh dan setia kepada keputusan tokoh agama. ${ }^{6}$

Berdasarkankan beberapa hal di atas, dapat dipahami bahwa jemaah mempunyai pemahaman atau persepsi terhadap khotbah Jumat berbahasa Arab, mereka sangat mematuhi ketetapan tokoh agama terhadap pelaksanaan khotbah Jumat berbahasa Arab karena itu merupakan apa yang telah dijalankan dari dulu sampai sekarang. Bagi mereka mematuhi apa yang ditetapkan oleh tokoh agama adalah suatu keharusan selama itu baik dan tidak menimbulkan perpecahan. Dengan mengikuti dan mematuhi apa telah menjadi kebijakan dan keputusan bersama, maka kehidupan beragama di Desa Puput akan aman dan tidak menimbulkan permasalahan yang menimbulkan perselisihan dan perpecahan.

\section{2) Sebagai Wujud Mempertahankan Warisan Turun-temurun}

Kemudian Rukimin menjelaskan bahwa masyarakat Desa Puput merupakan masyarakat yang masih sangat menghargai dan menjunjung tinggi warisan yang ditinggalkan oleh para leluhur. Apalagi dalam urusan peribadatan khususnya dalam pelaksanaan khotbah Jumat berbahasa Arab. Masyarakat sebagai jemaah menganggap khotbah Jumat berbahasa Arab sebagai sutau warisan yang harus dipertahankan karena mengingat sampai saat ini Desa Puput adalah satu-satunya Desa yang dalam Khotbah Jumatnya masih

\footnotetext{
${ }^{4}$ H. Hasan M. Amin, ketua masjid Al-Hidayah, Wawancara, Puput 13 Juli 2018

${ }^{5}$ Suhar, masyarakat, Wawancara, Puput 13 Juli 2018.

${ }^{6}$ Nomli, Masyarakat, Wawancara, Puput 22 Juli 2018
} 
berbahasa Arab. ${ }^{7}$

Berdasarkan tanggapan di atas, bahwa masyarakat Desa Puput menganggap khotbah Jumat berbasa Arab disamping merupakan hasil musyawarah yang dijadikan kebijakan dari tokoh agama, selain itu juga adalah warisan turun-temurun dari leluhur mereka yang harus dijaga dan dipertahankan. Hal ini yang menjadikan Desa Puput mempunyai ciri khas tersendiri yaitu khotbah Jumat berbahasa Arab.

Ungkapan di atas, sesuai dengan pandangan Setiadi bahwa kebiasaan yang telah berlangsung secara turun-temurun yang masih dilakukan merupakan warisan yang akan menjadi suatu konsep sejarah sebagai suatu kenyataan. ${ }^{8}$

Lebih lanjut terkait pernyataan di atas, Andi selaku tokoh pemuda mengatakan bahwa sepengetahuannya, Desa Puput adalah satu-satunya Desa yang khotbah Jumatnya masih berbahasa Arab. Di sini dirinya melihat dan menyimpulkan bahwa ini adalah keunikan tersendiri bagi saya, dan ini benar-benar merupakan warisan yang sudah terjadi dari dulu dan harus dipertahankan. ${ }^{9}$

Pernyataan di atas diperkuat dengan pernyataan infoman lainnya, yaitu disampaikan oleh Yusuf selaku tokoh pemuda mengungkapkan bahwa baginya khotbah Jumat berbahasa Arab di Desa Puput sangat berbeda dengan khotbah Jumat di daerah-daerah lain yang menggunakan bahasa Indonesia. Meskipun tidak memahami secara total makna khotbah, namun sangat khusyuk mendengarkan khotbah ini. Hal ini pun diperkuat karena khotbah Jum'a berbahasa Arab memiliki sejarah yang sangat menarik, sehingga menjadikan khotbah Jumat ini adalah sebagai warisan turun-temurun bagi masyarakat Desa Puput. ${ }^{10}$

Berdasarkan pernyataan di atas, khotbah Jumat berbahasa Arab dianggap sebagai warisan turun-temurun yang ditinggalkan para leluhur yang mengakar kuat dalam diri masyarakat yang harus dipertahankan oleh generasi muda.

Ungkapan di atas, sesuai dengan pandangan Krech dan Crutchfield bahwa persepsi dipengaruhi oleh variabel fungsional berupa kebutuhan, suasana hati, pengalaman masa lampau, dan sifat individual lainnya. ${ }^{11}$

Lebih lanjut terkait pernyataan di atas, Samson selaku khatib menjelaskan bahwa khotbah Jumat berbahasa Arab ini bukanlah hanya sebagai syarat sah salat Jumat, tetapi juga adalah harta warisan yang diwariskan oleh pendahulu kami kepada generasi penerus. Sudah seharusnya sebagai generasi penerus untuk menjaga warisan yang ditinggalkan supaya tidak pudar ditelan oleh zaman. Ini adalah salah satu bentuk penghormatan kepada leluhur dengan menjaga apa yang telah dititipkan. Dan dirinya berharap para pemuda sebagai generasi peneruspun selalu senantiasa menjaga warisan ini. ${ }^{12}$

Dari beberapa hal yang dijelaskan di atas, dapat dipahami bahwa jemaah menganggap khotbah Jumat bukan hanya sekedar syarat sahnya salat Jumat, akan tetapi khotbah Jumat berbahasa Arab adalah warisan yang harus mereka jaga dan pertahankan sebagai masyarakat yang menjunjung tinggi nilai budaya dan tradisi. Kemudian apa yang telah diwariskan kepada mereka akan selau senantiasa mereka sebagai salah satu bentuk penghormatan kepada para leluhur mereka yang mempunyai jasa besar dalam mengajarkan ajaran Islam di Desa Puput

\section{3) Khotbah Jumat Sebagai Dorongan untuk Mempelajari Bahasa Arab.}

Berdasarkan yang disampaikan oleh infomasn yairu Dahri jemaah salat Jumat Masjid Al-Hidayah Desa Puput menjelaskan bahwa dirinya memang tidak mengerti dengan bahasa Arab. Namun karena khotbah Jumat di Masjid Al-Hidayah berbahasa Arab, hal ini akhinya menjadi tantangan agar mengerti bahasa Arab, yakni hal tersebut bisa dicapai dengan cara mempelajari bahasa Arab. Artinya dengan mempelajari bahasa Arab minimal bisa memahami dengan maksud dan tujuan khotbah Jumat kami. ${ }^{13}$

Hal di atas diperkuat oleh Muslimin selaku pengurus TPA Al-Hidayah yang menjelaskan dalam pemahamannya khotbah Jumat berbahasa Arab tentunya terdapat kejanggalan, dimana khotbah berbahasa Arab, namun para jemaah tidak mengerti dan tidak memahami bahasa Arab. Kemudian timbul perasaan di dalam diri dan dorongan untuk mempelajari bahasa Arab, agar sebagaijemaah yang mendengararkan khotbah bisa memahami isi khotbah yang di sampaikan oleh khatib. ${ }^{14}$

Kemudian informan lainnya yaitu Manusta menjelaskan bahwa khotbah Jumat berbahasa Arab yang disampaikan khatib terdapat makna tersirat di dalamnya, yaitu dengan menggunakan bahasa Arab seakan-akan

\footnotetext{
${ }^{7}$ Rukimin, Tokoh adat, Wawancara, Puput 14 Juli 2018

${ }^{8}$ Elly Setiadi, Ilmu Sosial dan Kebudayaan Dasar, (Bandung: Kencana Prenada Media Group 2010), hlm. 8

${ }^{9}$ Andi, masyarakat ( pemuda), Wawancara, Puput 14 Juli 2018

${ }^{10}$ Yusuf, masyarakat (pemuda), Wawancara, Puput 14Juli 2018

${ }^{11}$ Sarlito Wirawan Sarwono, Teori-teori..., hlm. 94

${ }^{12}$ Samson, Wawancara, Puput 13 Juli 2018

${ }^{13}$ H. Dahri, masyarakat, Wawancara, Puput 13 Juli 2018

${ }^{14}$ H. Muslimin, pengurus TPA Al-Hidayah, Wawancara, Puput 13 Juli 2018
} 
terbiasa mendengarkan bahasa Arab. Namun itulah yang menjadikan khotbah berbahasa Arab ini menarik. Karena ketidakpahaman akan maksud khotbah Jumat berbahasa Arab maka timbul dorongan untuk mempelajari bahasa Arab, sekaligus harapan bagi kami kepada sarjana pendidikan agar bisa memberikan masyarakat pengajaran mengenai bahasa Arab. ${ }^{15}$

Berdasarkan ungkapan di atas, khotbah Jumat berbahasa Arab bisa menjadi pendorong semangat masyarakat untuk mempelajari bahasa Arab, sekaligus menjadi harapan agar para sarjana pendidikan bisa memberikan pengajaran bahasa Arab kepada masyarakat.

Dari berbagai tanggapan yang disampaikan informan juga dipahami bahwa jemaah terbiasa mendengarkan bahasa Arab dan sebagai pendorong untuk mempelajari bahasa Arab, pandangan itu sesuai dengan pandangan para ulama yang beralasan bahwa berkhotbah dengan bahasa Arab supaya manusia ada keinginan mempelajari bahasa Arab yang merupakan bahasa Al-Quran. ${ }^{16}$

Dilihat dari sisi pendidikan, hal ini juga tentunya bisa menjadi pendorong semangat bagi generasi muda untuk mempelajari bahasa Arab agar mereka tidak seperti orang tua mereka yang tidak mengerti dengan bahasa Arab. Tentunya mereka ingin lebih baik dari orang tua mereka. Jika generasi muda memahami bahasa Arab, mereka akan menjadi tenaga pengajar bagi masyarakat Desa Puput itu sendiri dalam mempelajari bahasa Arab. Dan tidak menutup kemungkinan nantinya masyarakat Desa Puput bisa memahami bahasa Arab.

\section{4) Sebagai Wujud Toleransi Terhadap Perbedaan Pendapat}

Beberapa informan mempunyai pemahaman dengan perpsektif yang berbeda dengan apa yang disampaikan oleh informan-informan sebelumnya. Infoman yang bernama Sapitra salah satu jemaah menjelaskan bahwa dirinya kurang sepakat jika di Masjid Al-Hidayah Desa Puput berkhotbah dengan bahasa Arab. Hal yang mendasari dirinya kurang sepakat adalah karena dirinya yang tidak memahami bahasa Arab dan isi dari khotbah Jumat itu sendiri. Oleh karena itu dirinya merasa tidak mendapatkan apapun dari khotbah Jumat yang dia dengarkan. Meskipun demikian, dia tetap tidak ingin memaksakan pengurus Masjid untuk menganti khotbah Jumat berbahasa Arab, karena dia menganggap jika pengurus Masjid mempunyai pendapat yang berbeda dengan dirinya, dan dia mengatakan perbedaan pandangan ini merupakan salah satu bentuk toleransi dan bentuk menghargai perbedaan pendapat yang perlu dipetahankan dan bisa dijadikan contoh bagi yang lainnya ${ }^{17}$

Ungkapan di atas, sesuai dengan pandangan Sarlito Wirawan Sarwono bahwa kebutuhan, baik itu kebutuhan sesaat maupun menetap pada diri seseorang akan menyebabkan perbedaan persepsi. ${ }^{18}$ Kemudian infoman yang bernama Zuni juga menjelaskan bahwa menuutnya khotbah Jumat berbahasa Arab kurang tepat karena seharusnya khotbah itu bisa memberikan pelajaran dan pendidikan mengenai hal keagamaan kepada para jemaah. Jika khotbah ini dilaksanakan dengan bahasa Arab, maka jemaah yang tidak mengerti dengan bahasa Arab tidak akan paham dengan isi khotbah, dengan kata lain para jemaah tidak mendapatkan apapun dari khotbah yang mereka dengar. Tetapi ini adalah keputusan dari pengurus Masjid dan para tokoh agama, tentunya mereka punya pendapat sendiri mengenai pelaksanaan khotbah Jumat berbahasa Arab ini dan saya sebagai masyarakat yang tidak ingin adanya perselisihan, maka saya menghargai pendapat pengurus Masjid dan para tokoh agama sebagai wujud toleransi akan perbedaan pendapat. ${ }^{19}$

Wawancara dengan beberapa beberapa infoman selaku jemaah salat Jumat di atas, dapat dipahami bahwa ada sebagian masyarakat yang kurang setuju atau kurang sepakat dengan pelaksanaan khotbah berbahasa Arab di Masjid Al-Hidayah Desa Puput. Hal yang mendasari mereka adalah karena khotbah Jumat berbahasa Arab belum bisa memberikan pendidikan agama bagi masyarakat. Namun yang menjadi poin pentingnya meskipun mereka kurang setuju dengan hal tersebut, mereka tetap menghomati dan menghargai pendapat yang telah disepakati oleh pengurus Masjid dan para tokoh agama sebagai wujud toleransi. Selain mereka menghargai perbedaan pendapat, mereka juga tidak ingin menimbulkan suatu permasalahan apalagi perselisihan hanya karena perbedaan pendapat terhadap khotbah Jumat berbahasa Arab yang selama ini dilaksanakan di Desa Masjid Al-Hidayah Desa Puput.

\section{Kesimpulan}

\footnotetext{
${ }^{15}$ Manusta, masyarakat, Wawancara, Puput 14Juli 2018

${ }^{16}$ Mahmud asy-syafrawi, Khotbah Cara ..., hlm. 83

${ }^{17}$ Sapitra, masyarakat, Wawancara, Puput 13 Juli 2018

${ }^{18}$ Sarlito Wirawan Sarwono, Psikologi Sosial: Individu dan Teori-Teori Psikologi Sosial Cet.III (Jakarta: Balai Pustaka , 2002), hlm. 94

${ }^{19}$ Zuni, masyarakat, Wawancara, Puput 13 Juli 2018
} 
Masyarakat Desa Puput mempunyai persepsi yang berbeda terhadap khotbah Jumat berbahasa Arab, secara mayoritas masyarakat setuju dengan pelaksanaan khotbah Jumat berbahasa Arab dengan alasan khotbah berbahasa Arab memberikan pemahaman kepada masyarakat untuk patuh kepada tokoh agama, melestarikan bahasa Arab dalam ritual ibadah, menyadarkan masyarakat tentang pentingnya bahasa Arab dan juga bisa mendorong masyarakat untuk mempelajari bahasa Arab, namun sebagian masyarakat yang kurang setuju dengan khotbah Jumat berbahasa Arab, karena bagi mereka khotbah Jumat berbahasa Arab ini tidak bisa memberikan pengetahuan kepada masyarakat selaku jemaah, tetapi mereka tidak ingin memaksakan kehendak mereka meskipun kurang setuju dengan khotbah Jumat berbahasa Arab dengan alasan menghargai perbedaan pendapat dan sikap toleransi.

Saran dari peneliti terhadap penelitian ini didasarkan pada kesimpulan peneliti mengenai pelaksanaan Khotbah Jumat berbahasa Arab di Desa Puput Keamatan Simpang Katis Kabupaten Bangka Tengah adalah sebagai berikut

1. Khotbah Jumat berbahasa Arab di Desa Puput memberikan pengaruh terhadap masyarakat Desa Puput, diantaranya bisa membentuk sikap patuh kepada tokoh agama, melestarikan budaya, mendorong untuk mempelajari bahasa Arab, dan membentuk sikap toleransi. Karena hal inilah khotbah Jumat berbahasa Arab di Desa Puput masih terus bertahan sampai saat ini.

2. Bagi masyarakat Desa Puput yang tidak memahami khotbah Jumat berbahasa Arab agar berusaha memahami isi dari khotbah Jumat berbahasa Arab, sehingga dengan memahami isi dari khotbah Jumat masyarakat bisa mengerti maksud dan tujuan dari khotbah Jumat yaitu mengingatkan untuk meningkatkan ketakwaan kepada Allah. Kemudian agar masyarakat bisa mempertahankan sikap saling menghargai setiap perbedaan pendapat yang terjadi di tengah-tengah masyarakat untuk mempertahankan kedamaian dan tujuan bersama.

3. Bagi pengurus Masjid dan tokoh agama supaya bisa mencari solusi untuk meningkatkan pengetahuan masyarakat mengenai pendidikan Islam bagi masyarakat, karena masyarakat tidak mendapatkan pengetahuan dari pelaksanaan khotbah Jumat karena masyarakat tidak memahami isi dari khotbah Jumat. Kemudian agar tokoh agama dan pengurus Masjid bisa mendengarkan masukan dan bisa mempertimbangkan tanggapan dari sebagian masyarakat yang kurang setuju dengan khotbah Jumat berbahasa Arab sebagai antisipasi agar tidak timbul suatu permasalahan yang bisa saja datang dikemudian hari.

\section{Daftar Pustaka}

Al-jaziri, Syeikh Abddurahman. 2010. Kitab Shalat Fiqih Empat Mazhab.

Jakarta: Hikmah PT. Mizan publika.

Asy-syafrawi, Mahmud . 2014. Khotbah Cara Rasulullah Tata Cara Khotbah Yang Baik Seperti Yang Dilakukan Rasulullah. Yogyakarta: Mutiara Media

Az-Zuhaili Wahbah. 2010. Fiqih Islam Wa Adilatuhu Jilid 2. Jakarta: Gema Insani.

Hassan. A. 1983. Soal Jawab tentang Masalah Agama 1 Cet. ke VII. Bandung: CV. Diponegoro.

Hasan. A. 1980. Tarjamah Bulughul-Maram, Bandung: CV. Diponegoro.

Imam, Alwisral Zaidallah dan Khaidir khatib Bandaro, 2005. Strategi Dakwah Dalam Membentuk Da'i dan Khatib Profesional.Jakarta: Kalam Mulia.

Imam, Alwirsal Zaidallah dan Khaidir Khatib Bandaro. 2002. Strategi Dakwah dalam Pembentukan Da'I dan Khatib Profesioanal. Jakarta: Kalam Mulia.

Kamus Bahasa Indonesia untuk Pelajar,. 2011. Jakarta: Badan Pengembangan dan Pembinaan Bahasa.

Noor, Juliansyah. 2015. Metodologi Penulisan Skripsi, Tesis, Disertasi, dan Karya Ilmiah. Jakarta: Kencana,

Qoyyim, Ibnu al- Jauziyah, 2009. Fikih Salat Lengkap. Yogyakarta: Pustaka Fahima.

Setiadi, Elly. 2010. Ilmu Sosial dan Kebudayaan Dasar. Bandung: Kencana Prenada Media Group.

Shodiq dan Shalahuddin Chaery, 2006. Kamus Istilah Agama. Bandung: Sinar Baru Algresindo. 
Slameto, 2003. Belajar dan faktor-faktor yang memepengaruhiny. Jakarta: Rieneka Cipta.

Wirawan, Sarlito Sarwono. 2002. Psikologi Sosial: Individu dan Teori-Teori Psikologi Sosial Cet.III Jakarta: Balai Pustaka 